\title{
Interest Rate Pass-Through and Monetary Transmission in Lebanon Loan Market
}

\author{
Buthina M. A. Muhtaseb \\ Department of Economics, Business School, University of Jordan, Amman, Jordan
}

Email address:

b.muhtaseb@ju.edu.jo,b.muhtaseb@hotmail.com

\section{To cite this article:}

Buthina M. A. Muhtaseb. Interest Rate Pass-Through and Monetary Transmission in Lebanon Loan Market. International Journal of Business and Economics Research. Vol. 6, No. 1, 2017, pp. 1-6. doi: 10.11648/j.ijber.20170601.11

Received: December 31, 2016; Accepted: January 12, 2017; Published: February 6, 2017

\begin{abstract}
We examine the symmetric and asymmetric interest rate pass-through under the fixed exchange rate system in Lebanon using monthly data from 1998:01 to 2016:06. Employing the Johansen cointegration approach, it is found that the pass-through in Lebanon is overshooting, which could be attributed to information asymmetries in the market. Furthermore, the asymmetric behavior of the commercial banks has been investigated by applying the methodology developed by Enders and Chumrusphonlert (2004). The results show that the interest rate on loans responds differently to monetary policy shocks.
\end{abstract}

Keywords: Interest Rate, Pass-Through, Information Asymmetry, Lebanon

\section{Introduction}

The choice of a monetary anchor has important impacts on the effectiveness of monetary policy tools. The objectives of monetary policy may not be consistent with each other. In an open economy with free capital mobility, if the monetary authority decides to target exchange rate, it has to abandon its economic independence as suggested by the impossible trinity. The credibility and effectiveness of monetary policy is determined by its ability to use its monetary instruments to achieve the primary and secondary goals of price stability, economic growth and employment. This credibility is not only determined by the choice of monetary regime but also by the market structure.

The monetary policy has different channels through which it could pass changes to affect the behavior of market agents. The most traditional and important channel, highlighted by Keynes, is the interest rate channel. Keynes thinks that this monetary policy channel can affect investment decisions and consumption decisions on durable goods [22]. Hence, in case of deflation, expansionary monetary policy through decreasing the level of nominal interest rate will lead to increase aggregate demand by lowering the cost of borrowing. In this channel, the financial intermediaries should transmit the authority's message to the public by lowering their interest rates charged on loans. The official interest rate sets by the central bank represents the marginal cost of funding for the financial intermediaries [34].

If monetary policy is effective, a one percent change in the official interest rate should be fully transmitted to interest rates charged by financial intermediaries. However, in an inefficient market, the full interest rate pass-through from the central bank to financial intermediaries cannot take place. The market structure of banking sector may dominate the presumed role of monetary policy and, consequently, the pass-through might be either incomplete or overshooting. This could be attributed to information asymmetries, switching costs or concentration in the banking market structure [11]. In addition, commercial banks may respond differently to monetary policy. In concentrated loan markets, they tend to respond quicker to positive monetary policy shocks than negative shocks [19]. That is, banks in imperfect competitive market change their interest on loans quicker upward than downward widening their profit margins. The structure performance hypothesis that reflects the non-competitive pricing behaviour is explained by Hannan and Berger (1991) Berger and Hannan (1989) who show that banks are able to adjust their interest rates quicker upward on deposit and downward on loans in concentrated markets.

Exploring these issues in more depth is of crucial importance for researches and monetary policymakers in different countries, particularly those which are functioning as financial hubs for their regions, such as Lebanon. The 
banking sector in this small open country was the most advanced in the Middle East region before the (1975-1990) civil War. Its position has deteriorated during the war, but has recently recovered and become one of the most dynamic regional banking sectors [4]. Lebanon has adopted a softpegged exchange rate system since December 1997. The central bank with a soft-peg can maintain some room to adjust its interest rate at its own discretion. In fact, Lebanon's monetary authorities can influence the timing of the variation in interest rates and the extent of movement of this variation [3].

The main goal of this paper is to assess the effectiveness of the monetary policy interest rate transmission mechanism in Lebanon. Specifically, the study aims to:

1) measure the size and speed of the interest rate passthrough

2) examine the asymmetric behavior of commercial banks

3) Investigate the existence of the market power in the Lebanese loan market

To do so we use monthly date from January 1998 to June 2016, and employ the Johansen (1991) and Enders and Chumrusphonlert (2004) to examine the interest rate passthrough and the asymmetric behavior of commercial banks, respectively.

The contribution of this study is twofold. First, it provides assessment and analysis on several aspect of the interest rate transmission mechanism in a country with a significant financial position in the region, for a recent period of time using high frequency data. It is among the few attempts on the pass-through in the loan market. Second, it tests for asymmetries of the adjustment of the retail rates to changes in official interest rate. We believe that understanding the interest rate pass-through and the asymmetric effects is significant for policymakers. Hence, we hope that this study has some interesting policy insights for the regulatory authorities in Lebanon.

The remainder of the paper consists of four sections. Section two reviews the related literature. The methodology is illustrated in section three. In section four, we describe the data and discuss the results, while in section five we provide the conclusions.

\section{Overview of the Literature}

In monetary policy literature, the research on the interest rate pass-through has been the subject matter of a wide variety of works covering different countries, periods of time, estimation methods as well as interest rate sets. ${ }^{1}$ The early works of Hannan and Berger (1991) and Neumark and Sharpe (1992) on the interest rate adjustment in the US banking sector, have been followed by the studies of Cottarelli and Kourelis (1994) and Borio and Fritz (1995), who find that the short term adjustment of lending rates across individual countries is sluggish, but the long-run pass-

1 The terminology "Interest rate pass-through" refers to the process through which an adjustment in policy rate is transmitted to retail rates [11]. through is complete for most countries investigated. The euro area has attracted many researches, such as Mojon (2000), Toolsema et al. (2001), De Bondt (2002), Sander and Kleimeier (2004) and De Bondt (2005). The findings of latter suggest that the pass-through from the money market rate to bank retail rates is incomplete, and that there is evidence of asymmetric adjustment of bank's retail rates to changes in monetary market rates. A comparative study on the interest rate pass-through from money market rate to bank lending rate in the euro area and the US has been carried out by Kwapil and Scharler (2010). Using Engle-Granger cointegration and ARDL methods, the results of the study show that interest rate pass-through is faster in the US compared to euro area countries.

A rapid growth of empirical research on other countries and regions has occurred during the last decade. Wang and Lee (2009) conducted a study on nine Asian countries and the USA. This study provides evidence of complete passthrough in the US, but not in the analyzed Asian countries. Furthermore, the USA and three out of nine Asian countries showed asymmetric behavior in the adjustment of lending rates. On the other hand, Tai et al. (2012) carried out a research covering the Asian countries only, and show that the transmission from money market rate into deposit and lending rates is slow and sluggish, and most of the countries have slower adjustment rates after the 1997 crisis. In Central American countries, Cas et al. (2011) find that the pass-through of policy rate to market rates has been weaker and slower in forty countries compared to six large countries in the region, which are selected as benchmarks.

Research on the same topic for single country studies is numerous. A recent example can be for Mongolia Doojav and Kalirajan (2016) examine the interest rate pass-through of the money market interest rate to bank lending and bank deposit interest rates employing linear and nonlinear ARDL models. The findings show that the bank deposit rate has a higher long-run interest rate pass-through and slower adjustment than the bank lending rate. Asymmetric pass- through exists. There are few studies focusing on or at least touching upon the analysis of Lebanon or Middle Eastern countries on interest rate pass-through. The only study available for Lebanon is that of Daccache and Nawar, which focuses on deposit market pass-through, while the current study analyzes the pass-through of Lebanese loan market. The study aims to identify the short and long run pass-through in a response to interest rate shocks for the 2003-2011 period employing the Error correction model. The authors use the LIBOR as a proxy for market interest rate shocks and the banking sector average rate as a proxy for interest rates paid by Lebanese banks on customer deposits. In addition, the study measures the speed of adjustment applying an impulse response function. The findings suggest that $6.8 \%$ of a market shock will be passed-through immediately, while the final passthrough rate is $33 \%$.

The paper conducted by Poddar et al. (2006) examined the monetary transmission for Jordan. Various transmission 
channels have been investigated, focusing on the central bank operating target, i.e. the real 3-month $\mathrm{CD}$ rate. A VAR approach provides evidence that the $\mathrm{CD}$ rate affects bank retail rates, and that monetary policy is effective in influencing foreign reserves and not output. The study for Egypt carried by Al-Mashat (2008) focused on the transmission mechanism in light of a shift to inflation targeting. Different channels are examined in a VAR model. The exchange rate channel seems to play a strong role, while most other channels are rather weak. Espinoza and Prasad (2012) investigated the monetary policy transmission in the GCC countries employing a VAR model. The results show that the pass-through of policy interest rates to retail rates is less than complete, owing mainly to the shallowness of the money markets and the manner in which GCC central banks operate.

Based on the above literature review, findings on the interest rate pass-through process, remain inconclusive owing to the differences in the factors influencing them. Several studies have focused on exploring the determinants of passthrough transmission. Saborowski and Weber (2013) conducted a research assessing the determinants of interest rate transmission for a sample of a large number of countries, which has been divided into eight groupings. The study aims to identify the determinants of effective transmission from central bank policy rates to retail lending rates. These factors are: Indicators of regulatory quality, inflation, financial development and dollarization, exchange rate flexibility, banking sector competition, as well as assets quality and liquidity. The findings from the structural panel VAR model indicate that industrial countries tend to have a higher passthrough, largely due to its high exchange rate flexibility amid more developed financial system. The result for the group of Middle East countries, to which Lebanon belongs shows much lower pass-through owing to the rigid exchange rate regimes, as well as the high liquidity and non-performing ratios.

\section{Methodology}

To form a relationship runs from the official interest rate to that on loan, the stationary of the variables should be checked. If the two variables are not found to be stationary at level but at first difference, the cointegrated series will be stationary. We apply the Johansen approach to estimate this long-run relationship. The general equation can be shown as follows.

$$
\Delta A_{t}=\alpha+\beta \Delta Z_{t-1}+\sum_{i=1}^{p-1} \theta A_{t-i}+\varepsilon_{t}
$$

Where $A_{t}$ represents a vector of endogenous variables and $\beta$ reflects information on the long run relationships between the variables. The Johansen reduced rank long-run regression between the official interest rate and the interest rate on loan can be represented as follows:

$$
\begin{gathered}
\operatorname{LIR}_{t}=\tau_{0}+\tau_{1} O I R_{t}+u_{t} \\
\Pi=\alpha \beta
\end{gathered}
$$

$\mathrm{LIR}_{\mathrm{t}}$ is the interest rate on commercial banks loans at time $t, \mathrm{OIR}_{\mathrm{t}}$ is the official interest rate set by the central bank at time $\mathrm{t}, \mathrm{tau}_{0}$ is the markup/markdown intercept on loan interest rate, and $u_{t}$ is the idiosyncratic error term. $\tau_{1}$ or $\beta$ reflects the degree of interest rate pass-through and its estimated value should be between zero and one. The passthrough is described as sticky if $\tau_{1}$ is less than one [2]. A value of one denotes a complete pass-through whereas a value exceeds one indicates an overshooting in the passthrough which is attributed to information asymmetries in the market [11]. $\alpha$ represents the speed of adjustment to disequilibrium at which retail interest rates respond to changes in official interest rates. The speed of adjustment for the official interest rate should be insignificant because the official interest rate should be treated as weakly exogenous as the casual nexus runs from the official interest rate to retail interest rate and not the opposite.

Johansen proposes two ratios of maximised likelihood functions, i.e. the maximal eigenvalue, or $\chi$-max statistic, and the trace test, where the null hypothesis is that $r$ cointegrating vectors exist. We then connect the short-run with the longrun dynamics under symmetry and asymmetry assumption via the error correction term.

$$
\Delta L I R_{t}=\delta_{0}+\delta_{1} \Delta O I R_{t}+\sum_{q=1}^{p} \delta_{2} O I R_{t-q}+\sum_{i=1}^{n} \gamma L I R_{t-i}+\lambda e c t_{t-1}+v_{t}
$$

$\Delta$ denotes the first difference of loan and official interest rates. $\delta_{1}$ and $\delta_{2}$ refer to the short run pass-through and the parameters of the lagged exogenous variable, respectively. $\gamma$ is the coefficient of the lagged dependent interest rates. $\lambda$ indicates the speed of adjustment when interest rates on loan responds similarly to changes in official interest rates. ect $t_{t-1}$ is the residual of the long run relationship at time $(\mathrm{t}-1)$. The sign of $\lambda$ should be negative to ascertain stationary. $v$ is the idiosyncratic error term.
Following the methodology of a threshold autoregressive error correction model by Enders and Chumrusphonlert (2004), we decompose the error correction term into two series where the threshold value is set to zero:

$$
\begin{aligned}
& \text { ect }^{+}=\text {ect if ect }>0 \\
& \text { ect }^{+}=0 \text { if ect }<0 \\
& \text { ect }^{-}=\text {ect if ect }<0
\end{aligned}
$$


ect $^{-}=0$ if ect>0

The asymmetric equation is presented as:

$$
\Delta L I R_{t}=\delta_{0}+\delta_{1} \Delta O I R_{t}+\sum_{q=1}^{p} \delta_{2} O I R_{t-q}+\sum_{i=1}^{n} \gamma L I R_{t-i}+\lambda e c t^{+}{ }_{t-1}+\lambda e c t^{-}{ }_{t-1}+v_{t}
$$

$\lambda_{1}$ represents the speed of adjustment to disequilibrium when loan interest rates are above the equilibrium level, and $\lambda_{2}$ is the speed of adjustment when loan interest rates are below the equilibrium level. A Wald test is applied to examine whether $\lambda_{1}=\lambda_{2}=0$. The asymmetric hypothesis is accepted if the P-value is less than the level of significance. If $\lambda_{2}$ is found to be larger than $\lambda_{1}$ the response of rate on loan is quicker upward than downward.

\section{Data Collection and Results}

We import data on Lebanese interest rate on certificate of deposit (CD) and loan from the statistical database of the
Banque du Liban. The data cover the monthly span from January 1998 to June 2016, over which the country adheres to the \$de jure\$ and \$de facto\$ fixed exchange rate system. The rate on central bank certificates of deposit serves as the main reference interest rate for the economy [28].

We first test for the stationarity of the interest rate on CD and loan by the mean of Dickey and Fuller (1979) and Perron (1989) tests. The optimal lag length of the test equation is determined by the Schwartz information criterion and a constant is imposed into the test equation. The results, shown in Table 1, indicate that both interest rates are stationary at first difference, which forms the possibility for a long-run relationship between the two interest rates.

Table 1. Unit Root Test (Level-First Difference).

\begin{tabular}{lllll}
\hline Variable (ADF) Test & At Level & Probability & At First difference & Probability \\
\hline CD & -2.18 & 0.24 & -7.62 & 0.00 \\
Loan & -2.5 & 0.12 & -5.83 & 0.00 \\
Variable (PP) Test & At Level & Probability & At First difference & Probability \\
CD & -2.8 & 0.24 & -6.99 & 0.00 \\
Loan & -2.29 & 0.17 & -15.82 & 0.00 \\
\hline
\end{tabular}

We proceed to look for a cointegrating relationship between the interest rates on $\mathrm{CD}$ and loan by applying the Johansen (1991) cointegration test. Both maximum likelihood tests, i.e., Trace and Max-Eigen tests point out that a one cointegrating relationship exists between the interest rate on CD and that on loan, as shown in Tables 2.

Table 2. Trace and Max-Eigen Test.

\begin{tabular}{ll}
\hline \multicolumn{2}{l}{ Trace and Max. Eigen Test Statistics and Critical Value } \\
\hline Trace statistic-None; Null: $r \leq 1$ & $40.09^{*}$ \\
critical value $\% 5$ & 20.26 \\
Max-Eigen statistic-None; Null: $r \leq 1$ & $40.24^{*}$ \\
critical value $\% 5$ & 15.98 \\
Trace statistic-at most one; Null: $r \leq 1$ & 8.84 \\
critical value $\% 5$ & 9.16 \\
Max-Eigen statistic-at most one; Null: $r \leq 1$ & 8.84 \\
critical value $\% 5$ & 9.16 \\
\hline
\end{tabular}

Note: *significant at 5\% level according to Osterwald-Lenum (1992) critical values of model 2 (Constant in the cointegration space).

Commercial banks should adjust their interest rates charged on loan based on changes in official interest rates, which are set independently of banks retail interest rates. Therefore, the official interest rate, i.e., interest rate on $\mathrm{CD}$, should be treated as weakly exogenous. In other mean, $\alpha$ of the $\mathrm{CD}$ rate should not be significantly different from zero. The cointegrated estimate of the magnitude of the relationship show that the pass-through in Lebanon is overshooting. This finding is in line with Bogoev and Petrevski (2012) for Macedonia which is also a small open economy with a fixed exchange rate. The result for Lebanon may reflect a high degree of information asymmetries in the Lebanese loan market. The estimated $\beta$ is around 1.9, which means that a unit percent change in $\mathrm{CD}$ rate is resulted after one lag in $1.9 \%$ changes in loan rate. $\alpha$ of the rate on $\mathrm{CD}$ is found to be weakly exogenous.

Table 3. Cointegration Test.

\begin{tabular}{ll}
\hline Loan (normalized) & \\
\hline Optimal Lag Length & 2 \\
beta & -0.1044 \\
alpha (loan) & $-0.087(0.01)$ \\
alpha (CD) & $0.006(0.009)$ \\
\hline
\end{tabular}

Note: Standard errors are in parentheses

We estimate the short-run dynamics of interest rate under symmetry and asymmetry assumption. The parsimonious symmetric and asymmetric dynamic model of equations are estimated and presented in Table 4 and Table 5, respectively. Both estimated models is lack of autocorrelation and heteroscedasticity problems. The CUSUM test for model stability, shown in Figure 1 and Figure 2 indicates that the cumulative sum of the recursive residuals lies inside the area between the $\% 5$ critical lines. A Wald test is performed to examine asymmetries in the loan market. The null hypothesis that $\lambda_{1}$ is not different from $\lambda_{2}$ cannot be accepted as the critical value of the $F$ test's critical value is less than the calculated value. The asymmetric results indicate that commercial banks are quicker to increase their interest rates on loan while they are slower to decrease them. This reflects 
that the bank concentration hypothesis applies to the Lebanese loan market. Indeed, the concentration degree in the Lebanese banking sector was relatively high in the beginning of the 1990s, and become higher in recent years [8]. $\mathrm{R}^{2}$ and adjusted $\mathrm{R}^{2}$ value as well as the lagged value of the monetary policy tool are very low. These results provide evidence that effectiveness of monetary policy in Lebanon is questioning.

Table 4. Symmetric Model.

\begin{tabular}{llll}
\hline Coefficient & & Std. Errors & t-Statistic \\
\hline $\mathrm{C}$ & -0.001 & 0.02 & -0.3 \\
$\Delta \mathrm{CD}_{\mathrm{t}-7}$ & $0.24^{* * *}$ & 0.08 & 2.95 \\
$\Delta \operatorname{loan}_{\mathrm{t}-1}$ & $-0.21^{* * *}$ & 0.07 & -3.05 \\
$\mathrm{Ect}_{\mathrm{t}-1}$ & $-0.07^{* * *}$ & 0.01 & -5.01 \\
$\mathrm{R}^{2}$ & 0.21 & & \\
Adjusted R $^{2}$ & 0.2 & & \\
F-statistics & 17.71 & & \\
Durbin-Watson stat. & 1.95 & & \\
Breusch-Godfrey LM Test & 0.95 & Prob. $\mathrm{F}(2,202)=0.38$ \\
Harvey Test & 0.42 & Prob. $\mathrm{F}(3,205)=0.74$ \\
\hline
\end{tabular}

Note: $* * *, * * *$ denote significance at $1 \%, 5 \%$ and $10 \%$, respectively. Symmetric model shows the effect of policy rate on loan rate where the speed of adjustment to monetary policy innovations is indifferent. The null hypothesis of Breusch-Godfrey LM test and Harvey test is that there is no autocorrelation and heteroscedasticity, respectively.

Table 5. Asymmetric Model.

\begin{tabular}{llll}
\hline Coefficient & & Std. Errors & t-Statistic \\
\hline $\mathrm{C}$ & -0.021 & 0.02 & -0.79 \\
$\Delta \mathrm{CD}_{\mathrm{t}-7}$ & $0.25^{* * *}$ & 0.08 & 3.04 \\
$\Delta \operatorname{loan}_{\mathrm{t}-1}$ & $-0.20^{* * *}$ & 0.07 & -2.81 \\
$\mathrm{Ect}^{+}$ & $-0.06^{* * *}$ & 0.02 & -3.27 \\
$\mathrm{Ect}^{-}$ & $-0.14^{*}$ & 0.08 & -1.6 \\
$\mathrm{R}^{2}$ & 0.20 & & \\
Adjusted $\mathrm{R}^{2}$ & 0.19 & & \\
Wald Test: F-Statistic (2,204) & $12.82^{* * *}$ & & \\
F-statistics & 13.42 & & \\
Durbin-Watson stat. & 1.95 & & \\
Breusch-Godfrey LM Test & 0.79 & Prob. $\mathrm{F}(2,202)=0.45$ \\
Harvey Test & 1.16 & Prob. $\mathrm{F}(4,204)=0.32$ \\
\hline
\end{tabular}

Note: $* * *, * *, *$ denote significance at $1 \%, 5 \%$ and $10 \%$, respectively. Symmetric model shows the effect of policy rate on loan rate where the speed of adjustment to monetary policy innovations is indifferent. The null hypothesis of Breusch-Godfrey LM test and Harvey test is that there is no autocorrelation and heteroscedasticity, respectively.

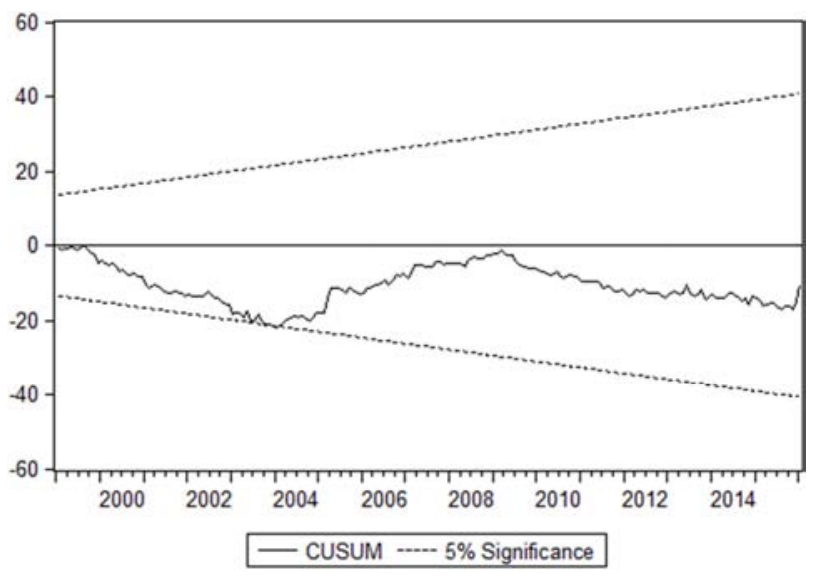

Figure 1. Chow Test for Symmetric Model.

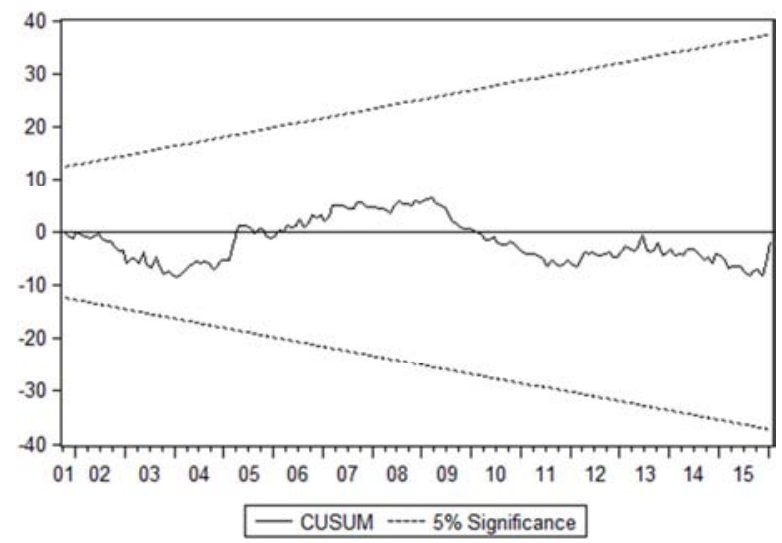

Figure 2. Chow Test for Asymmetric Model.

\section{Conclusions}

We assess the interest rate pass-through in Lebanon to shed light on the credibility of monetary policy in the loan market over the monthly span from 1998:01 to 2016:06. We apply the Johansen approach to examine the size and speed of adjustment to disequilibrium in the long run. We also estimate the short-run dynamic error correction parsimonious model under the assumption of symmetry. In addition, we test whether asymmetries exist in the Lebanese loan markets following the Methodology developed by Enders and Chumrusphonlert (2004). Two dummy variables are imposed onto the conditional dynamic model to reflect the trajectory of loan interest rates when it is above or below the zero equilibrium level.

The findings suggest that the interest rate pass-through in Lebanon is overshooting. The asymmetric behavior of commercial bank is found to exist. This reflects a high degree of imperfect competition in the Lebanese loan market. Given this, the effectiveness of monetary policy in Lebanon is dubious. Therefore, measures to boost competition in the financial system, and increase exchange rate flexibility in addition to developing the financial sector could help to achieve a symmetric adjustment of retail rates, and hence, improve the effectiveness of the monetary policy.

\section{References}

[1] Al-Mashat, R. A., 2008. Monetary policy in Egypt: A retrospective and preparedness for inflation targeting. Egyptian Center for Economic Studies.

[2] Amarasekara, C. (2005). Interest rate pass-through in Sri Lanka. Staff Studies $35(1 / 2), 1\{32\}$.

[3] Association Banks of Lebanon, 2013, The Lebanese banking sector: Pillar of Lebanon's stability.

[4] Awdeh, A. (2016). The impact of variable interactions on lebanese banks fragility. International Journal of Economics and Finance 8 (8), 111.

[5] Berger, A. N. and T. H. Hannan (1989). The priceconcentration relationship in banking. The Review of Economics and Statistics, $291\{299$. 
[6] Bogoev, J. and G. Petrevski (2012). Interest rate pass-through in a small open economy with a fixed exchange rate-the case of macedonia. Procedia-Social and Behavioral Sciences 44, $125\{133$.

[7] Borio, C. E. and W. Fritz (1995). The response of short-term bank lending rates to policy rates: a cross-country perspective.

[8] Cobham, D. (2010). Monetary policy strategies, financial institutions and financial markets in the middle east and north Africa: an overview.

[9] Cottarelli, C. and A. Kourelis (1994). Financial structure, bank lending rates, and the transmission mechanism of monetary policy. Sta_Papers $41(4), 587\{623\}$.

[10] Daccache, R. and C. Nawar. Pass-through of interest rate shocks to Lebanese deposit rates.

[11] De Bondt, G. (2002). Retail bank interest rate pass-through: New evidence at the euro area level.

[12] De Bondt, G. J. (2005). Interest rate pass-through: Empirical results for the euro area. German Economic Review 6 (1), $37\{78\}$.

[13] Dickey, D. A. and W. A. Fuller (1979). Distribution of the estimators for autoregressive time series with a unit root. Journal of the American statistical association 74 (366a), $427\{431\}$.

[14] Doojav, G.-O. and K. Kalirajan (2016). Interest rate passthrough in Mongolia. The Developing Economies 54 (4), $271\{291$.

[15] Enders, W. and K. Chumrusphonlert (2004). Threshold cointegration and purchasing power parity in the paci c nations. Applied Economics 36 (9), $889\{896\}$.

[16] Espinoza, R. A. and A. Prasad (2012). Monetary policy transmission in the GCC countries.

[17] Hannan, T. H. and A. N. Berger (1991). The rigidity of prices: Evidence from the banking industry. The American Economic Review, $938\{945\}$.

[18] Johansen, S. (1991). Estimation and hypothesis testing of cointegration vectors in gaussian vector autoregressive models. Econometrica: Journal of the Econometric Society, $1551\{1580\}$.

[19] Karagiannis, S., Y. Panagopoulos, and P. Vlamis (2011). Symmetric or asymmetric interest rate adjustments? evidence from greece, bulgaria and slovenia. $15(3), 370\{385\}$.

[20] Kwapil, C. and J. Scharler (2010). Interest rate pass-through, monetary policy rules and macroeconomic stability. Journal of International Money and Finance 29 (2), 236\{251\}.
[21] Medina Cas, S. C., A. Carri on-Men endez, and F. Frantischek (2011). The policy interest-rate pass-through in central america. IMF Working Papers, $1\{21\}$.

[22] Mishkin, F. S. (2007). The economics of money, banking, and financial markets. Pearson education.

[23] Mojon, B. (2000). Financial structure and the interest rate channel of ECB monetary policy.

[24] Neumark, D. and S. A. Sharpe (1992). Market structure and the nature of price rigidity: evidence from the market for consumer deposits. The Quarterly Journal of Economics, $657\{680\}$.

[25] Association of Lebanon, A. B. (2013). The Lebanese banking sector: Pillar of Lebanon's stability.

[26] Osterwald-Lenum, M. (1992). A note with quantiles of the asymptotic distribution of the maximum likelihood cointegration rank test statistics 1 . Oxford bulletin of economics and statistics 54 (3), $461\{472\}$.

[27] Perron, P. (1989). The great crash, the oil price shock, and the unit root hypothesis. Econometrica: Journal of the Econometric Society, $1361\{1401\}$.

[28] Poddar, M. T., M. M. Goswami, M. J. Sole, and V. E. Icaza (2006). Interest rate determination in Lebanon. Number 6-94. International Monetary Fund.

[29] Saborowski, C. and M. S. Weber (2013). Assessing the determinants of interest rate transmission through conditional impulse response functions. Number 13-23. International Monetary Fund.

[30] Sander, H. and S. Kleimeier (2004). Convergence in eurozone retail banking? What interest rate pass-through tells us about monetary policy transmission, competition and integration. Journal of International Money and Finance 23 (3), $461\{492\}$.

[31] Tai, P. N., S. K. Sek, and W. M. Har (2012). Interest rate passthrough and monetary transmission in asia. International Journal of Economics and Finance 4 (2), 163.

[32] Toolsema, L. A., J.-E. Sturm, J. De Haan, et al. (2001). Convergence of monetary transmission in emu new evidence. Technical report, CESifo Group Munich.

[33] Wang, K.-M. and Y.-M. Lee (2009). Market volatility and retail interest rate pass-through. Economic Modelling 26 (6), $1270\{1282\}$.

[34] Weth, M. A. (2002). The pass-through from market interest rates to bank lending rates in germany. Deutsche Bundesbank, Economic Research Centre Discussion Paper (11/02). 